\title{
A reforma administrativa da Nova Zelândia nos anos 80-90: controle estratégico, eficiência gerencial e accountability ${ }^{1}$
}

\author{
Wagner Carvalho
}

\section{Introdução}

A década de 80 assistiu a um movimento geral de reformas de Estado e reformas administrativas em diversos países, que pode, resumidamente, ser expresso em termos de dois objetivos básicos: redução do déficit público e diminuição do crescimento do setor estatal. Os governos destes países realizaram uma tentativa de mudança, tanto da dimensão

Mestrando em administração pública da EBAP/FGV/RJ, analista do Banco Central do Brasil institucional quanto da ideológica, visando a uma reorganização do setor público: mudança institucional no sentido de que seria necessário alterar tanto a estrutura como o funcionamento do setor público, possibilitando um acréscimo de sua autonomia, maior eficiência na consecução dos resultados, e ao mesmo tempo e em contrapartida, um maior controle daquele setor por parte da sociedade. Na dimensão ideológica, por representar uma mudança no paradigma que tem orientado a burocracia estatal: a chamada "burocracia weberiana" deveria dar lugar a uma "burocracia gerencialista", com a conseqüente introdução de práticas típicas de mercado na administração pública.

Esse movimento parece ter-se universalizado: tanto os governos de países que dispõem de setores públicos considerados grandes - como a Suécia - mas também governos de países com pequenos setores estatais — como a Inglaterra - têm conduzido reformas de Estado de natureza e objetivos similares.

Essa tendência reformista do Estado cursa, em paralelo, e mesmo decorre das grandes transformações que tiveram origem a partir do fim da Guerra Fria, sendo potencializada pelo desmoronamento do comunismo e da crise do Estado de Bem-Estar. A superação da polarização NorteSul gerou um padrão bem mais monocórdico, facilitando a implantação 
de padrões universais de consumo e orientados segundo as forças de mercado. Os Estados, segundo os teóricos reformistas, acham-se despreparados para as novas pressões desse ambiente globalizado e por isto precisam ser repensados. ${ }^{2}$

O diagnóstico e a justificativa que nortearam - e ainda norteiam - esse movimento de reformas também são comuns: o setor público caracteriza-se por ser "inchado", ineficiente, abrangendo áreas da economia às quais poderiam ser assumidas pela iniciativa privada e, principalmente, pelo setor estatal considerado como o maior responsável pelo déficit público. Em outro nível, presume-se que o setor privado é, geralmente, mais eficiente que o público na produção de bens e serviços. Daí, uma atividade somente deve ser realizada pelo Estado, quando houver uma razão bastante persuasiva que justifique tal finalidade. ${ }^{3}$

Mudanças dessa natureza envolvem um enorme esforço, o qual não se resume somente em uma vontade política dos novos governantes, mas pressupõe uma correlação de forças políticas majoritárias, que forneça a sustentação necessária para a aprovação de profundas alterações na ordem constitucional-legal. Caracteristicamente, esses processos são normalmente lentos e dependentes de acordos e alianças políticas; o que indica, para sua viabilização, uma continuidade das práticas políticas postas em ação. O processo político, assim, precisa ser dimensionado para mais de um período legislativo, o que significa que a fração política dominante deve ter, como um dos principais objetivos, a necessidade de se manter uma continuidade no poder, ou seja, de antemão, está prevista a necessidade de reeleição.

Esta foi a concepção básica das reformas na Inglaterra, e assim também ocorreu na Nova Zelândia. Outros países tentaram a mesma solução, tais como Austrália, Dinamarca, Suécia. Desta forma, uma variável que parece importante para a concretização das reformas é a que representa a manutenção da correlação das forças políticas reformistas — bloco político dominante bastante sólido que consegue reeleger-se por vários mandatos consecutivos e dar continuidade ao processo. Países que conseguiram implementar reformas consideradas radicais - Inglaterra e Nova Zelândia - apresentaram essa característica. ${ }^{4}$ Até que ponto essa variável pode ser considerada como determinante para o aspecto da "radicalidade reformista" é um aspecto que precisa ser melhor avaliado.

Na Nova Zelândia, as reformas ocorreram a partir de 1984, com a chegada ao poder do Partido Trabalhista, sendo consolidadas com a reeleição em 1987. Esse processo teve continuidade e mesmo foi intensificado a partir de 1990, com a vitória eleitoral do Partido Nacional. Antes mesmo, e ao longo dos anos 70 e 80, organizações intergovernamentais como Organização para a Cooperação e Desenvolvimento Econômico (OCDE) e o Fundo Monetário 
Internacional (FMI) indicaram a necessidade de privatização das empresas estatais e de uma mudança drástica no setor público. Essa receita reformista requeria forte redução dos custos financeiros, diminuição do número de empregados do setor estatal e chamava atenção para a questão da irresponsabilidade que imperava no setor público. Essas duas organizações, fortemente influenciadas pela abordagem teórica da Public Choice, também propiciaram treinamento para os burocratas do setor econômico e fiscal do Estado, o que explica a origem das propostas desses burocratas para a reforma administrativa, como se verá mais adiante.

Em sua primeira parte, o artigo discute a situação da Nova Zelândia no período pré-reforma, delimitando um ponto de partida que permite posteriormente, a comparação do panorama anterior com o cenário atual, ou seja, avaliar os resultados da reforma.

Em seguida, estudam-se as formas incrementadas no nível da burocracia dirigente, e, especialmente, os contratos de gestão entre os executivos-chefe e os ministros e a assunção de responsabilidades pela consecução dos resultados contratados.

Posteriormente, procurar-se-á mostrar como ocorrem, hoje, na Nova Zelândia, as contratações no serviço público, e de uma forma geral, estudar a questão da política de recursos humanos e seus subsistemas: seleção, qualificação, avaliação de performance e indicadores de desempenho.

Por último, traça-se um perfil da Nova Zelândia pós-reforma, e, de forma resumida, discute-se o ferramental teórico que deu suporte às reformas naquele país. Dentro deste escopo, e baseado na literatura disponível, procuraremos responder algumas questões, tais como: quais as vantagens e desvantagens da política de avaliação periódica dos contratos de gestão entre executivos e ministros? Com a implementação desses mecanismos, os ministros tornaram-se, efetivamente, mais capacitados para exercer controle sobre os departamentos e agências? E os altos executivos, responsáveis pelos departamentos, tornaram-se mais responsáveis perante os ministros?

\section{O modelo administrativo anterior a 1984}

O modelo administrativo neozelandês obteve êxito, no século XIX, no desmonte do aparato burocrático colonial e na subseqüente substituição deste aparato por um novo modelo de administração de caráter estatizante. Essa nova administração, baseada no modelo weberiano, possibilitou a eliminação dos abusos e vícios coloniais, permitindo uma escalada na ascensão social, melhorou a qualificação dos funcionários através de políticas de qualificação e garantiu condições de trabalho suficientemente estáveis. ${ }^{5}$ 
O êxito inicial do novo modelo acabou por constituir uma cultura hostil às mudanças que, com o passar do tempo, e em decorrência da aceleração do ritmo das transformações econômicas, sociais e políticas, - mas precisamente com a crise dos anos 70 - passou a ameaçar a estabilidade e sobrevivência do próprio sistema. Fez-se necessário, mais uma vez, empreender esforços para renovar aquele modelo administrativo, tarefa agora dificultada por atitudes e procedimentos já ossificados pela tradição.

Até os anos 70, a economia neozelandesa logrou um respeitável crescimento e estabilidade econômica, graças a uma balança de pagamentos amplamente favorável, fruto da exportação de matérias-primas e da possibilidade de captação de crédito para a cobertura dos gastos governamentais. Com a degradação da economia mundial estas condições desapareceram, a balança comercial apresentou seus primeiros déficits, a inflação sofreu sensível elevação, assim como a taxa de desemprego. O setor público, pouco adaptado às situações adversas, passou a apresentar seguidos déficits orçamentários, escala crescente de endividamento, fatores estes evidenciados na desvalorização da moeda.

Três revisões sucessivas no sentido de compatibilizar os pagamentos e receitas do setor público foram realizadas na década de 60 e 70, não resultando, entretanto, em mudanças significativas.

Especialmente a partir dos anos 80, organizações de caráter intergovernamental, tais como o FMI e a OCDE reforçaram a necessidade de uma revisão do setor público. As principais dificuldades apontadas por essas organizações em relação ao setor público eram:

- crescimento dos custos financeiros;

— gerência financeira irresponsável;

- aumento do empreguismo.

A área de recursos humanos também era problemática. Antes dos anos 80, a Nova Zelândia não dispunha de um sistema formal de acompanhamento da performance dos altos escalões das burocracias estatais. Os executivos chefes eram escolhidos a partir de uma lista de servidores públicos mais experientes. Esta escolha poderia ser objeto de veto pelos ministros, mas, tradicionalmente, esta prerrogativa raramente era utilizada. Os executivos selecionados, geralmente com média de idade em torno de 45-50 anos, permaneciam nestes departamentos até a idade de 60 anos, constituindo o chamado "quadro permanente". 6

Apesar das tentativas de reorganização mencionadas, o setor público continuou a se expandir. O gasto público total, na Nova Zelândia, apesar de ter apresentado, neste período, taxa de elasticidade superior a 1 (um) em relação ao PIB, ficou, em contrapartida, abaixo da média dos países da OCDE. ${ }^{7}$ (Tabela 1) 
Tabela 1: Indicadores econômicos governamentais anteriores às reformas

\begin{tabular}{l|c|c|c|c}
\hline & $\begin{array}{c}\text { Déficit em conta } \\
\text { corrente - \% } \\
\text { do PIB }\end{array}$ & $\begin{array}{c}\text { Déficit fiscal } \\
-\% \text { PIB }\end{array}$ & $\begin{array}{c}\text { Gasto } \\
\text { governamental } \\
\text { total - \% PIB }\end{array}$ & $\begin{array}{c}\text { Emprego no } \\
\text { Setor Público- } \\
\text { \% da força de } \\
\text { trabalho }\end{array}$ \\
\hline Austrália & 3,9 & 4,2 & 38,6 & 17,4 \\
\hline Dinamarca & 4,0 & 9,2 & 61,2 & 30,2 \\
\hline Nova Zelândia & $\mathbf{6 , 0}$ & $\mathbf{8 , 9}$ & $\mathbf{3 5 , 3}$ & $\mathbf{2 4 , 9}$ \\
\hline Suécia & 3,3 & 7,1 & 66,3 & 32,9 \\
\hline Média OCDE & 0,3 & 4,2 & 45,8 & 18,0 \\
\hline
\end{tabular}

1 - 1982 para Dinamarca, Suécia; 1983 para Austrália; 1984 para Nova Zelândia.

2 - Emprego no Setor Público: 1984 para todos os quatro países.

(Retirado e adaptado de: SchwarTz, 1994, op.cit., p. 53)

Antes das reformas atuais, existiam três tipos de empresas públicas - SOE's: ${ }^{8}$

a) departamento do governo: assessoria, regulamentação e funções comerciais, tais como Serviço Postal, Serviço Florestal, Ministérios do Trabalho, Desenvolvimento e Energia.

b) companhias governamentais com responsabilidade limitada, regidas pelo Companies Act, de 1955, tendo, usualmente, o Ministro das Finanças como único acionista. Exemplos dessas companhias: Air New Zealand, Bank of New Zealand, Petrocorp e a Shipping Corporation.

c) corporações públicas estabelecidas sob o Acts of Parliament, tais como Housing Corporation, a Railways Corporation e o Rural Bank.

As SOE's estavam envolvidas em uma grande diversidade de atividades, como seguros, atividades bancárias, construção civil, habitação, atividades florestais, turismo, comércio, radiodifusão, telecomunicação, transporte, produção de energia e sua distribuição, manufaturas, produção primária, pesquisa e desenvolvimento, assessoria e serviços. Em alguns casos, tais como distribuição de energia e serviços de telecomunicação, grandes empresas públicas desfrutavam de monopólio; em outros casos, como atividades bancárias e seguros, elas competiam diretamente com o setor privado. Obviamente, com o Estado envolvido em tão extensa lista de atividades, ele se tornara responsável por um impacto importante em toda performance da economia. Este nível de intervenção foi o responsável, segundo Boston, por uma taxa de crescimento econômico abaixo dos padrões internacionais: em termos de renda per capita, o país, que detinha o terceiro lugar na classificação internacional até o início dos anos 50, caiu para vigésimo quinto lugar na metade dos anos 80 . 


\section{Os objetivos e os princípios da reforma}

No final de 1985 o governo anunciou as principais linhas que norteariam a reorganização administrativa do setor público. Em setembro de 1986 foi introduzida a legislação State-Owned Enterprises Bill, dando início à execução efetiva da reforma. O Treasure estimou que, para o período 1986/1987 as medidas iriam reduzir o gasto do governo em torno de 900 milhões de dólares neozelandeses; para 87/88, em 1.200 milhões de dólares e 1.400 milhões de dólares para o período de $88 / 89 .{ }^{9}$

De acordo com Richardson, os objetivos da reforma buscaram melhorar a performance e garantir controle social, transparência e responsabilização sobre os atos dos agentes estatais - accountability, conforme abaixo especificado:

- melhorar a relação custo-efetividade da produção de bens e serviços pelo setor estatal;

- melhorar a qualidade desses bens e serviços;

— tornar o setor público provedor de bens e serviços mais responsável perante as necessidades dos consumidores;

- dar aos representantes eleitos maior controle sobre os recursos que foram utilizados.

Richardson ${ }^{10}$ cita os seguintes princípios que nortearam das reformas: controle estratégico, clareza na definição dos objetivos, descentralização, accountability, competição e presunção sobre maior eficiência do setor privado.

Boston $^{11}$ enumera oito princípios, que, por sua abrangência, englobam e explicam melhor a dinâmica das reformas. São eles:

1) Separação das funções comerciais das não-comerciais.

A justificativa baseia-se no conflito, na definição e execução do objetivos. Quando uma agência possui objetivos conflitantes, geralmente, nenhum desses objetivos é bem realizado. A forma de resolver tal problema foi separar as atividades comerciais das não-comerciais. O principal resultado tem sido remover as funções comerciais dos departamentos do governo, e colocá-las em corporações públicas independentes. De acordo com Richardson $^{12}$, a separação das atividades comerciais das não-comerciais alcança outro objetivo: deixa claro, de um lado, o núcleo do setor estatal e de outro, o setor empresarial do governo. Estes dois setores necessitam de diferentes estruturas organizacionais e regimes de accountability.

2) Separação entre as funções administrativa e de assessoria.

Este princípio relaciona-se à proibição de que as agências responsáveis pela administração e implementação das políticas forneçam consultoria aos ministros em matéria de políticas públicas. Noutro aspecto argumenta-se que os ministros devem dispor sempre de uma fonte alternativa de consultoria; ou seja, para cada visão de um problema, uma 
consultoria diversa. Por exemplo, na área de proteção ambiental, uma mesma agência não deverá fornecer consultoria nas áreas de conservação e desenvolvimento, ou em eficiência e eqüidade.

3) Princípio do "quem usa paga" (user-pays).

Este princípio afirma a necessidade de se cobrar o preço real pelos serviços e bens produzidos pelos departamentos e agências do Estado, no que se refere à comercialização intragoverno. Ele visa eliminar uma prática arraigada no serviço público, de se fazer um preço especial, sempre mais baixo, ou mesmo não se cobrar, quando o cliente era um órgão do próprio Estado. Os objetivos deste princípio são:

a) tornar claro para o administrador público que nada mais é de graça, e encorajar uma mudança de comportamento;

b) sendo o preço o mesmo, tanto o setor público quanto o privado, ambos são forçados a avaliar o quanto o serviço é realmente importante, o que proporciona economia;

c) aumentar a renda auferida com a prestação do serviço;

d) evitar desperdício, já que somente irá comprar aquele que realmente necessitar do serviço ou do produto.

4) Transparência na concessão de subsídios.

Desde a entrada em vigor do State-Owned Enterprises Act, de 1986, o principal objetivo das nove corporações públicas foi operar com a filosofia de sucesso gerencial, visando à obtenção de lucros. Ou seja, deverão ser "lucrativas e eficientes como as empresas que não são de propriedade da Coroa", e ao mesmo tempo, serem "boas empregadoras", exibindo "um senso de responsabilidade social". ${ }^{13}$

No caso de o governo necessitar de bens e serviços de uma empresa governamental (SOE), de natureza não-lucrativa, tal como a extensão de energia elétrica, ou de estradas de rodagem para áreas não economicamente rentáveis, ele deverá fazer um contrato formal com a empresa prestadora dos serviços.

O que se deseja é que serviços que necessitam ser subsidiados, sejam claramente definidos e publicamente abertos, ou seja, deve haver transparência no processo. ${ }^{14}$

5) Neutralidade competitiva.

Este princípio relaciona-se ao anterior. O seu objetivo é garantir uma competição justa entre as empresas do Estado e as empresas privadas. Ele garante que as empresas públicas deverão ser livres de entraves e controles burocráticos que as possam prejudicar na livre competição de mercado, e, ao mesmo tempo, garante uma igualdade de competição, não permitindo a elas privilégios especiais, tais como a manutenção de direitos de monopólio, garantia de clientela ou financiamento subsidiado.

Exige, também, que as novas SOE's adquiram seus bens e ativos do governo, após uma apropriada avaliação mercadológica. Isto tem provocado bastante controvérsia, porque diferentemente da avaliação de uma 
propriedade, que é relativamente fácil de ser feita, a avaliação de recursos naturais, tais como um reserva hídrica ou de carvão, uma reserva florestal, é bem mais complexa, e, sendo mal conduzida, pode impactar negativamente a performance e a estrutura de preços da empresa. ${ }^{15}$

6) Descentralização e aumento do poder discricionário do administrador.

A descentralização do processo decisório tem sido um elemento básico para conferir maior eficiência, adaptabilidade e responsabilidade à burocracia, na reforma neozelandeza.

Os administradores públicos detêm agora grande responsabilidade pelas decisões a respeito de compras, estabelecimento de preços, investimentos, delegação de autoridade para níveis de competência, etc. ${ }^{16}$

7) Melhoramento da accountability.

Ao lado do movimento pelo aumento da autonomia gerencial achase a questão da eficiência, eficácia e transparência dos controles financeiros das agências públicas — accountability, em relação ao Parlamento e ao Executivo. ${ }^{17}$

Na Nova Zelândia, a accountability é assegurada através de duplo acompanhamento: ministerial e parlamentar, visando verificar até que ponto a agência ou departamento cumpriu seus objetivos. As formas que facilitam esse processo podem ser resumidas da seguinte forma:

a) as agências governamentais devem estabelecer objetivos claros e específicos, indicadores de performance em conjunto com o ministro ao qual seja subordinada;

b) o relatório da agência deve estabelecer a relação entre o que foi realizado e o que foi estabelecido anteriormente;

c) regime de incentivos e sanções para os administradores;

d) reforma do Parlamento, concedendo-lhe maiores poderes para manter investigações e dotando-o de recursos para melhorar seu quadro de staff. ${ }^{18}$

8) Assistência durante o período de transição.

A reorganização administrativa do Estado não foi realizada sem traumas: alterou a vida de milhares de empregados públicos, com desemprego e aumento de preços ao consumidor. Compreendendo esta situação, e para minimizar os custos sociais decorrentes das mudanças, o governo introduziu várias medidas de caráter transitório. As mais importantes compuseram o Permanent Staff Deployment Package, negociado com representações de classe do setor público no final de 1986. Aos empregados considerados como excessivos na formação das novas SOE's, foram oferecidos quatro opções: aposentadoria precoce, retreinamento, recolocação em outro setor do governo, demissão voluntária, sendo que esta última forma foi oferecida pela primeira vez na história do serviço público da Nova Zelândia. ${ }^{19}$ 
O maior impacto da estratégia de corporatização foi sentida pelas comunidades cuja economia se baseava na extração de carvão, no setor de minas de carvão e pelos trabalhadores do setor florestal, gerando um clima de revolta, nestas regiões. ${ }^{20}$ Mesmo assim, apesar de todo sofrimento que decorreu das reformas, a opinião pública, pesquisada no início de 1987 , dava suporte às medidas saneadoras. Isto foi confirmado pela reeleição, em agosto de 1987, do governo trabalhista, o qual conseguiu ampla maioria.

\section{O processo e as etapas da reforma administrativa}

$\mathrm{Na}$ Nova Zelândia as empresas governamentais (State-Owned Enterprises - SOE) têm sido, há muito tempo, ineficientes na utilização dos recursos públicos e na ausência de accountability. Até recentemente, as reformas tinham sido realizadas de forma esporádica e limitadas no seu escopo. Entretanto, com a eleição do gabinete trabalhista, em julho de 1984, esta situação foi bastante alterada. O governo trabalhista transformou a administração da economia e implementou uma vasta reforma em vários campos da política pública, como política monetária e cambial, política salarial e de relações industriais, política de impostos, política comercial e política externa.

Estas mudanças na estrutura, organização e administração do Estado têm sido particularmente dramáticas e, sem dúvida, são as mais significativas reformas desde a ocorrida em $1912 .^{21}$

\subsection{As reformas do governo trabalhista: 1984 a 1990}

O processo de reforma teve início no primeiro dia do governo Lange, com a introdução da política de flutuação da moeda neozelandesa, o dólar da Nova Zelândia. Essa medida acelerou o processo geral de desregulamentação econômica, o que incluiu também a remoção dos controles e desburocratização das importações. No entanto, a principal meta do governo neste primeiro período foi a reforma administrativa do setor público. ${ }^{22}$

Três grandes iniciativas, neste sentido, foram anunciadas pelo governo durante o primeiro gabinete trabalhista, no período 1984-1987:

a) comercialização de muitas funções realizadas pelas organizações estatais;

b) separação, onde possível, das atividades comerciais dos departamento, das não-comerciais, e a transferência das atividades comerciais para “corporações públicas”. Em abril de 1987, nove novas SOE's, cobrindo uma larga escala de atividades comerciais - bancos, telecomunicações, serviços postais, etc., foram estabelecidas como companhias de estatuto de responsabilidade limitada, incorporadas sob o Companies Act, de 1955. A Tabela 2 detalha estas mudanças. 
Tabela 2: A reforma do setor estatal na Nova Zelândia (em vigor a partir de abril de 1987).

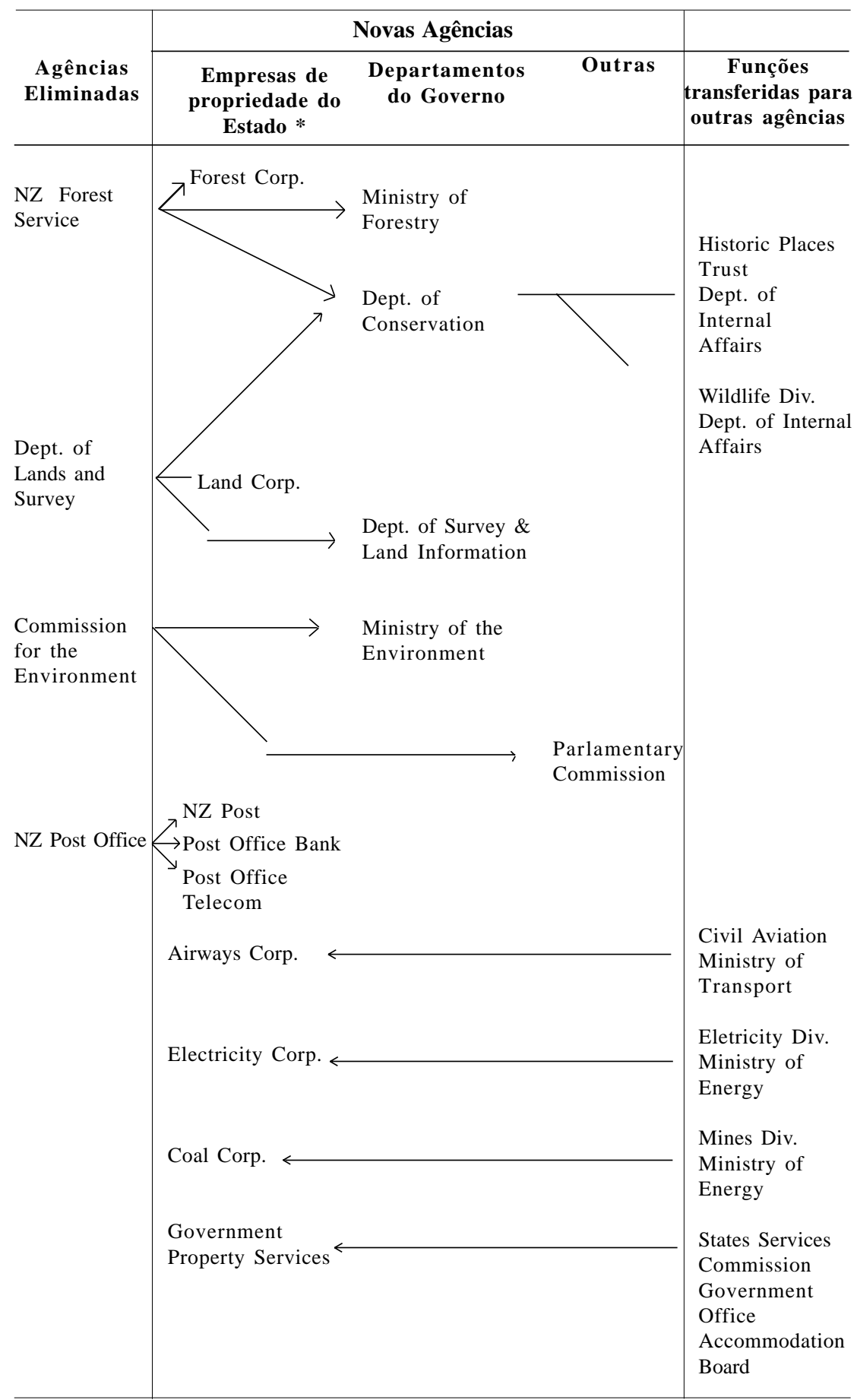

Fonte: Robert Gregory, The Reorganization of the Public Sector. In Boston, op. cit., 1987, p.425

* State Owned Enterprise (SOE) 
Cada uma dessas companhias tem o conjunto de diretores nomeados pelo governo. Dois acionistas - shareholders - o ministro das finanças e um outro ministro designado tornam-se responsáveis perante o Parlamento pelo acompanhamento de toda a performance das empresas. Em adição, cinco corporações foram alteradas, a partir da legislação existente desde 1986 - o State-Owned Enterprise Act, que possibilitou uma maior uniformidade, tanto da estrutura institucional como da política de controle. Foram afetados diretamente cerca de $60 \mathrm{mil}$ servidores públicos - aproximadamente $25 \%$ da força de trabalho do governo central - e realizada a transferência de bens públicos do Estado para novas corporações. ${ }^{23}$

c) o governo anunciou um plano para introduzir importantes mudanças no sistema de fixação de salário no setor público. A nova política procura caminhar de um sistema de pagamento centralizado para um sistema comparável ao do setor privado, de caráter descentralizado, com um sistema baseado na barganha ou negociação.

Além destas, outras medidas importantes foram introduzidas:

a) os administradores seniores ganharam bastante autonomia para utilização dos recursos;

b) os monopólios de algumas SOE's foram eliminados ou reduzidos;

c) novos pacotes de empregos para economistas e analistas financeiros foram introduzidos; algumas funções desempenhadas pelos departamentos governamentais passaram a ser desempenhadas pelo setor privado, a partir de contratações.

Durante este período, importantes iniciativas foram planejadas:

- reorganização dos governos locais, com a transferência de atividades comerciais sendo contratadas pela iniciativa privada.

- remodelação total da estrutura da administração do governo central, visando à formação de um núcleo do serviço público. O planejamento previa, por exemplo, de dez a doze ministérios, agrupados através de afinidades funcionais, tais como administração econômica, desenvolvimento social, ambiente, comércio, recursos nacionais e administração do setor público. Estes teriam a finalidade de produção e organização das informações, fornecer consultoria ao ministro, propor legislação e regulamentações, preparar propostas orçamentárias.

- estabelecimento de novas agências para implementar a política do governo. Cada agência seria operada de forma separada, com diretoria independente, mas todas sujeitas à orientação do governo. Este arranjo, permitiria aos ministros, livres da administração do dia-a-dia, dedicarem maior tempo às questões políticas e ao conjunto de prioridades.

O ritmo das reformas foi consideravelmente diminuído após a reeleição do gabinete trabalhista, em 1987, dando origem ao epíteto 'pause for a 
cup of tea' referindo-se ao Primeiro-Ministro Lange. O processo somente

foi acelerado novamente após 1990, com a renovação do gabinete e substituição do governo trabalhista pelo governo do Partido Nacional.

\subsubsection{A dinâmica e a lógica da reforma}

O governo trabalhista, por ocasião das eleições de 1984, foi bastante evasivo no que tange às reformas: o Policy Document, documento do Partido Trabalhista de 1984, dedicou menos que uma página relacionada diretamente aos serviços prestados pelo Estado, e na sua maior parte, endossava os arranjos organizacionais existentes, baseados no sistema de pagamento fixo e centralizado. Isto reafirmou a confiança do Partido em um ativo papel do Estado no desenvolvimento social e econômico do país. Entretanto, ele também sugeria importantes mudanças a serem feitas, como, por exemplo, iniciar e implementar novas idéias para melhorar serviços, aumentar a eficiência e, onde fosse apropriado, elevar a produtividade, dar maior flexibilidade e independência administrativa para gerenciar o pessoal do Estado.

Posições pró-reformas também ficaram evidenciadas nos escritos e em entrevistas de políticos mais antigos do partido, os quais se manifestavam favoráveis a mudanças significativas na estrutura do serviço público e no sistema de accountability financeira. Outras manifestações no mesmo sentido foram feitas pelos partidos de oposição, por comentaristas políticos, por experts em direito constitucional, e pela comunidade acadêmica. $^{24}$

Outra área favorável às mudanças estava dentro do próprio governo: eram os técnicos e especialistas do Treasure, que lamentavam a pobreza da economia e recomendavam políticas de mudanças, fornecendo sugestões como:

- perseguir uma política macroeconômica;

- liberação comercial;

- desregulamentação do trabalho;

- significativa redução do papel do Estado;

- maior ênfase na assistência e ao bem-estar;

— reforma do setor público;

— venda das melhores empresas do governo (SOE).

A base filosófica que orientou esse movimento era essencialmente ligada ao liberalismo econômico — individualismo, preferência pelo setor privado, limitado papel do Estado, confiança na competição de mercados livres e a escolha dos consumidores como forma de satisfazer às necessidades e desejos humanos. Os principais objetivos eram: alocação economicamente racional do recursos, rápido crescimento econômico, expansão da liberdade dos indivíduos e um sistema de bem-estar mais eqüitativo. 
No Economic Management, editado logo após as eleições de julho de 1984, afirmava-se a posição dos especialistas do Treasure, principalmente, no que tangia às deficiências dos outros departamentos do governo:

— a maioria dos departamentos do governo não tinham objetivos claramente definidos;

- a maioria dos departamentos não possuíam um plano de administração claramente especificado;

— os administradores tinham pouca liberdade para introduzir mudanças em seus departamentos visando alcançar seus objetivos. Faltava autonomia para, dentro de um determinado limite orçamentário, decidir como produzir melhores resultados;

- muita ênfase no controle das entradas - inputs, em vez de se enfatizar a consecução dos resultados - outputs;

— não existiam mecanismos efetivos de controle e avaliação de performances para os administradores dentro dos departamentos.

Além disto, havia outros fatores que estimularam o gabinete do Partido Trabalhista a executar as reformas, tais como:

a) a crise de confiança pela qual passava a moeda nacional, o déficit fiscal que alcançava a cifra de $9 \%$ do PIB, o déficit no comércio externo e o enorme peso da dívida externa;

b) o pensamento, em alguns setores do governo, de que, a menos que se tornassem as SOE's mais eficientes, as propostas de privatização acabariam tendo de ser aprovadas, devido às pressões da comunidade empresarial.

\subsection{Os principais instrumentos legais da reforma}

Três instrumentos ou diplomas legais transformaram as relações, e alteraram o status dos administradores, tanto nas agências estatais quanto nas empresas públicas: o primeiro dele, o State Owned Enterprise Act, de 1986, como citado anteriormente, separou as atividades comerciais mantidas pelo Estado das atividades de regulação e controle, corporatizando-as em nove grandes empresas comerciais (vide Tabela 2). Isto resultou, segundo Laking, ${ }^{25}$ na redução de cerca de 52 mil empregos no serviço público — de 88.000 em 1985 para 36.000 em 1993. Uma parte dessa força de trabalho foi aproveitada pelas novas empresas, mas uma quantidade considerável de pessoal ficou desempregada.

O segundo, o State Sector Act de 1988, e o Public Finance Act de 1989, editados após o período de reeleição e consequiente fortalecimento do governo trabalhista, estabeleceram novas formas de gestão e disciplina para o trabalho, e visaram ao setor não-comercial do Estado. O State Sector Act regulamentou e introduziu novas formas e prerrogativas, tanto para a questão dos direitos trabalhistas quanto para a questão 
salarial do serviço público, similares as linhas traçadas pelo Industrial Relations Act, de 1987, que regulamentou o setor privado. Alterou radicalmente as relações trabalhistas dos administradores públicos, que passaram a compor uma classe administrativa, a Senior Executive Service (SES). O Public Finance Act, de 1989, alterou a orientação dos controles financeiros realizados sobre as agências: de um sistema de controles baseado nas entradas ou input-oriented para um baseado nos resultados alcançados, ou seja, output/outcome-oriented controls.

Apesar de o gabinete trabalhista se mover em direção a uma filosofia de livre-mercado, ele se esquivou de executar um programa mais efetivo de privatização como o que foi perseguido, por exemplo, pela GrãBretanha e França. A razão disto decorre, em parte, da influência que exerceu a ala esquerda do governo trabalhista, e parte, pelo desejo de evitar medidas que provocassem rachas políticos dentro do Partido.

A entrada no poder do Partido Nacional, eleito em 1990, provocou uma intensificação das mudanças, principalmente através da ênfase na responsabilidade fiscal. Para isto, foi editado o Fiscal Responsability Act, em 1994, quarto diploma legal, tendo como princípio básico a redução total do débito público para níveis prudentes, ou seja, que o gasto total do governo em cada ano fiscal deveria ser inferior às receitas totais no mesmo exercício fiscal. ${ }^{26}$

\subsection{A reforma gerencial: controle estratégico, especificação de objetivos e responsabilização}

Visando retificar as deficiências na gerência do setor público, já apontadas anteriormente, foi realizada uma série de mudanças, cuja ênfase concentrava-se na clarificação dos relacionamentos cadeia hierárquica. $\mathrm{O}$ objetivo era evitar situações em que ocorressem conflitos de interesse, tal como uma agência responder hierarquicamente a mais de um ministro.

O setor público necessitava de uma estrutura que possibilitasse a especificação da performance desejada, uma apropriada delegação da tomada de decisão, acompanhamento dos contratos de gestão e uma cuidadosa aplicação de incentivos e sanções.

De acordo com o State Sector Act (1988) e o Public Finance Act (1989), cada departamento deve preparar, anualmente, um detalhado plano corporativo, ${ }^{27}$ que especifique seus outcomes e outputs e os indicadores de performance requeridos, baseados em critérios de qualidade, quantidade, prazos, etc.

Três conceitos, aqui, merecem destaques: outcomes, outputs e inputs. Os outcomes poderiam ser expressos como sendo os propósitos das atividades do governo. Clareando o conceito, o outcome representa o nível de abstração necessário que fornece aos ministros condições de 
concentrar seus esforços na dimensão estratégica e, conseqüentemente, ao conjunto de prioridades visando a uma boa alocação dos recursos públicos. Os outputs podem ser expressos em termos dos bens e dos serviços produzidos pelos departamentos do governo. Este conceito é tão importante na Nova Zelândia, que é considerado como central na compreensão da accountability. Os outputs de um determinado departamento são determinados pelo ministro e especificados em um contrato formal acordado entre o ministro e o executivo-chefe do departamento. Além disto, toda a alocação orçamentária dos departamentos é realizada com base nesses outputs. A ênfase nos inputs, ou seja, os recursos utilizados para produzir os outputs, era a prática adotada anteriormente, que resultou em uma enormidade de controles sobre a utilização desses recursos. Com a mudança de ênfase, de input para output, os executivos-chefes dos departamentos passaram a gozar de uma grande liberdade para utilização dos recursos.

Para isto, foi necessário deixar bem clara a linha de autoridade e responsabilidade entre a burocracia e o Executivo: as relações entre os executivos-chefes dos departamentos e os ministros foram simplificadas e pautadas pela accountability. Cabe ao ministro a tarefa de determinar as prioridades departamentais, especificar os outcomes desejados e os outputs que os departamentos devem alcançar. Além disto, deve monitorar a consecução dos resultados e a performance dos departamentos sob sua responsabilidade. De outra parte, os ministros são responsáveis pela escolha dos outcomes e dos outputs e respondem pelos seus atos diretamente ao Primeiro-Ministro e ao Parlamento. Ao executivo-chefe cabe garantir o alcance dos resultados requeridos pelo ministro, e, por outra parte, é o responsável direto por qualquer falha na consecução dos objetivos departamentais.

\subsubsection{Os contratos de gestão baseados em performance}

Os contratos de gestão baseados na performance constituem uma forma inovadora, havendo poucos países no mundo que utilizam este instrumento de controle gerencial. Eles representam uma forma prática e funcional de, a partir da definição e especificação dos outcomes e outputs dos departamentos, cristalizá-los na forma de um contrato formal, negociado entre o ministro e um executivo-chefe. De acordo com $o$ 'Guidelines for Preparing Chief Executives Performance Agreements', desenvolvido em 1989 pela SSC, ${ }^{28}$ o contrato de performance tem o propósito de definir, claramente, a responsabilidade e accountability entre as partes contratadas, principalmente no que se refere ao relacionamento entre o executivo-chefe e um ou mais ministros.

Três níveis devem ser considerados e incluídos na elaboração de um contrato de performance: 
a) nível pessoal: um contrato de performance pessoal entre o ministro e o executivo-chefe, o qual deve registrar os objetivos e as tarefas prioritárias e consensuais entre ambos, visando facilitar o relacionamento pessoal e direto durante a vigência do contrato;

b) nível departamental: um contrato operacional no nível de departamento, consistente com os elementos básicos do plano corporativo, envolvendo a produção de outputs e demais requisitos administrativos que foram contratados;

c) nível geral: um contrato geral de administração, que prescreve uma consistência entre as ações e os objetivos de todos os departamentos, incluindo as responsabilidades do executivo-chefe e os suportes relativos ao interesse público.

Visando desenvolver mecanismos que melhorassem a performance e minimizassem os comportamentos oportunísticos, foi criada uma nova estrutura de incentivos para a carreira dos executivos-chefes: a) forma de pagamento, fixada em contrato por tempo determinado; b) possibilidade de renegociação desses contratos; c) incremento salarial baseado na performance.

A alocação dos executivos-chefes passou a ser centralizada pelo Senior Executive Service (SES), podendo os mesmos serem contratados por um período que varia entre dois e cinco anos de contrato. A performance é avaliada anualmente pela State Services Commission (SSC), e a remuneração e promoção na carreira dependem da habilidade individual para alcançar os outputs contratualmente fixados durante as negociações com os ministros. ${ }^{29}$ É também responsabilidade da SSC a fixação da remuneração dos administradores. Os critérios para fixação da remuneração, a cargo da SSC, giram em torno do nível de responsabilidade, na importância da função e na quantidade de trabalho a ser realizado. As condições de contrato para cada função, apesar de serem negociadas entre a SSC e o chefe-executivo, devem estar de acordo com as linhas básicas traçadas pelo governo. ${ }^{30}$

Isto significa que os ministros podem agora concentrar-se na formulação estratégica maior, e ficam livres da estressante tarefa de negociação contratual com os executivos-chefes, o que, como foi dito acima, está a cargo da SSC.

Antes de outubro de 1990, quando a eleição do governo do Partido Nacional, poucos executivos-chefes alcançaram as metas negociadas com os ministros. No período de 1989-1990, somente 15 dos 30 executivos entrevistados por Whitcombe ${ }^{31}$ satisfizeram as cláusulas contratadas. Em 1991, Kim Bolger afirmara que somente uns poucos executivos-chefes ainda mantinham contatos com os ministros e atendiam à solicitação legal 
de apresentar o plano estratégico dos seus departamentos. Esta situação parece ter sido alterada no decorrer do ano de 1991. Cerca de dois terços dos ministros entrevistados afirmaram ter firmado contrato de performance com seus executivos.

Apesar de todo o otimismo sobre contrato de performance, certos ministros não estão convencidos dos benefícios que tal instrumento acarreta para a consecução dos resultados do governo. Consideram que os contratos não garantem uma boa performance, e além disto, baseiam-se na quantificação da performance, deixando de lado a dimensão qualitativa, que reside, justamente, no relacionamento entre ministro e executivochefe. Outro fator que compromete a realização dos objetivos é o freqüente turnover dos executivos-chefes, que reduzem a eficiência e efetividade do processo gerencial, ocasionado por trocas ministeriais devidas a mudanças no governo.

\subsubsection{As relações de trabalho no setor público}

Atualmente, todo o pessoal contratado pelo Estado é regido pelo Employment Contracts Act, a mesma legislação que vige no setor privado. Desta forma, os executivos-chefes de cada departamento têm autonomia e liberdade para nomear, demitir e promover seus funcionários. Os contratos podem ser firmados individual ou coletivamente, por departamento, e as negociações sobre condições contratuais são conduzidas, individualmente, departamento por departamento. Por outro lado, a forma de incremento salarial está sendo alterada: a fórmula clássica de incrementos anuais está sendo abandonada, para dar lugar a um sistema de bônus baseado em performance.

Novas formas de contratação e novos sistemas de recompensa têm sido experimentados. Por exemplo, existem possibilidades de uma grande flexibilização em termos de horas por dia de trabalho e empregos ocasionais. Segundo os reformadores, estes mecanismos beneficiam o empregador, pela economia que proporcionam, e agradam alguns empregados, que não dispõem de todo o horário diário para dedicar-se ao serviço público, seja por terem outras atividades fora do Estado, seja pela necessidade de uma maior assistência aos filhos.

\section{A situação atual}

Em um curto espaço de tempo, a Nova Zelândia tornou-se uma nação transformada: as condições vigentes até 1984, ano que marcou o início de uma década de grandes reformas do mercado, iniciadas com a eleição do governo trabalhista de David Lange, desapareceram: de uma 
das economias mais protecionistas tornou-se uma das mais abertas e produtivas.

O núcleo do serviço público, drasticamente reduzido, conta atualmente com apenas 38\% departamentos, cobrindo uma variedade de funções: implementação de políticas, serviços, operações comerciais. ${ }^{32}$

A Nova Zelândia começou seguindo a trilha percorrida pela Austrália, através de uma reforma microeconômica em $1984^{33}$ : desregulamentação econômica, tendo como ponto central a flutuação do dólar australiano.

Desde o advento da Lei de Contratos de Trabalho, que começou a vigorar em 1991, a Nova Zelândia experimentou transformações no relacionamento empregador-empregado e grandes avanços na produtividade da mão-de-obra. Sentenças judiciais com abrangência nacional deixaram de existir e a posição protegida dos sindicatos foi eliminada. Todos os trabalhadores passaram a estar empregados sob contratos individuais ou coletivos.

Devido ao superávit orçamentário alcançado - em torno de 2 a $3 \%$ do Produto Interno Bruto - além de um Banco Central com grande credibilidade, de uma conta corrente aproximando-se do equilíbrio e de um sistema industrial que realmente relaciona os aumentos de salários a ganhos em produtividade, os neozelandeses estão muito menos sujeitos a ter de enfrentar nova escalada de taxas de juros.

O crescimento do nível de empregos é o indicador mais óbvio do sucesso do mercado de trabalho. Este nível está crescendo em $4 \%$ ao ano - seu maior percentual em quase sete anos. À medida em que o crescimento do Produto Interno Bruto de 6,1\% aquece a economia, cresce o número de empregos e os salários sobem em quase todos os setores da Nova Zelândia. Os principais dados estão representados nas tabelas 3, 4, 5 e 6 , abaixo.

Alguns indicadores macroeconômicos indicam, entretanto, a necessidade de cuidados especiais: o déficit da conta corrente, que é de cerca de $1,4 \%$ do PIB, tende a aumentar substancialmente e a dívida externa líquida pode estourar a curto prazo. A dívida pública acumulada, no entanto, permanece alta, em torno de $39 \%$ da economia, o que, entretanto, poderá ser revertido com a entrada de recursos oriundos de uma forte campanha de privatização. Além disto, sua inflação é baixa e estável - em torno de 1 a $2 \%$ ao ano - e seu orçamento tende a um superávit. 
Tabela 3: Indicadores sociais - comparação entre o período pré-reforma e o pós-reforma.

(o Brasil está presente como fator comparativo)

\begin{tabular}{|c|c|c|c|c|c|c|c|c|}
\hline \multirow[t]{2}{*}{ Países } & \multicolumn{2}{|c|}{$\begin{array}{l}\text { Percentagem da } \\
\text { população com } \\
\text { acesso a serviços } \\
\text { médicos }\end{array}$} & \multicolumn{2}{|c|}{$\begin{array}{c}\text { Taxa de mortalidade } \\
\text { infantil }\end{array}$} & \multicolumn{2}{|c|}{$\begin{array}{c}\text { Analfabetismo } \\
\text { de adultos }\end{array}$} & \multicolumn{2}{|c|}{$\begin{array}{l}\text { Percentagem do gasto } \\
\text { em serviços sociais } \\
\text { em relação à despesa } \\
\text { total }\end{array}$} \\
\hline & 1980 & 1994 & 1980 & 1994 & 1980 & 1994 & 1980 & 1994 \\
\hline Austrália & 99 & - & 11 & 6 & $<5 \%$ & $<5 \%$ & 45,5 & 57,5 \\
\hline Nova Zelândia & - & 100 & 13 & 7 & $<5 \%$ & $<5 \%$ & 57,0 & 69,1 \\
\hline Japão & - & 100 & 8 & 4 & $<5 \%$ & $<5 \%$ & - & 59,2 \\
\hline Coréia & - & 100 & 32 & 12 & $<5 \%$ & $<5 \%$ & 22,0 & 32,0 \\
\hline Brasil & - & - & 74 & 56 & 17 & 17 & 32,3 & 36,7 \\
\hline
\end{tabular}

Dados: Banco Mundial. Relatório sobre o desenvolvimento mundial - 1996.

Tabela 4: Indicadores econômicos - comparação entre o período pré-reforma e o pós-reforma.

(O Brasil está presente como fator comparativo)

\begin{tabular}{l|c|c|c|c|c|c|c|c}
\hline Países & \multicolumn{2}{|c|}{$\begin{array}{c}\text { Taxa média de } \\
\text { crescimento anual(\%) } \\
\text { das exportações }\end{array}$} & \multicolumn{2}{c|}{$\begin{array}{c}\text { Taxa média de } \\
\text { crescimento anual(\%) } \\
\text { das importações }\end{array}$} & \multicolumn{2}{c|}{$\begin{array}{c}\text { Taxa média anual } \\
\text { de inflação }\end{array}$} & \multicolumn{2}{c}{$\begin{array}{c}\text { Superávit/déficit } \\
\text { global } \\
\text { (como \% do PNB) }\end{array}$} \\
\hline Austrália & $1980 / 90$ & $1990 / 94$ & $1980 / 90$ & $1990 / 94$ & $1973 / 84$ & $1990 / 94$ & 1984 & 1994 \\
\hline Nova Zelândia & 5,8 & 8,1 & 4,9 & 5,1 & 10,4 & 1,2 & $-2,5$ & $-2,9$ \\
\hline Japão & 6,6 & 5,4 & 4,6 & 5,5 & 13,6 & 1,2 & $-9,5$ & 0,8 \\
\hline Coréia & 13,7 & 7,4 & 11,2 & 7,7 & $5,9(* *)$ & 6,3 & $-2,3(*)$ & 0,3 \\
\hline Brasil & 6,1 & 6,6 & $-1,5$ & 8,5 & 71,4 & $1.231,5$ & $-3,6$ & $-4,0$ \\
\hline
\end{tabular}

Dados: Banco Mundial. Relatório Sobre o Desenvolvimento Mundial - 1996.

Tabela 5: Força de trabalho $x$ desemprego

\begin{tabular}{|c|c|c|c|c|}
\hline \multirow[t]{2}{*}{ Força de trabalho } & \multicolumn{4}{|c|}{ Valores Médios } \\
\hline & $-----\overline{\text { Unidade }}$ & $-\overline{1993}$ & $\overline{1994}-$ & $-\overline{1995}---$ \\
\hline Força total de trabalho & 1000 & $1.643,4$ & $1.693,2$ & $1.728,0$ \\
\hline Homens & 1000 & 928,8 & 949,1 & 968,8 \\
\hline Mulheres & & 714,6 & 744,2 & 759,3 \\
\hline Taxa de desemprego & $\%$ & 10,2 & 9,5 & 6,9 \\
\hline Homens & $\%$ & 10,7 & 9,6 & 6,9 \\
\hline Mulheres & $\%$ & 9,7 & 9,4 & 6,9 \\
\hline
\end{tabular}

Fonte: Nova Zelândia: http://www.govt.nz 
Tabela 6: Indicadores econômicos, sociais e demográficos da Nova Zelândia em comparação com alguns países que também passaram por reformas.

(O Brasil está presente como fator comparativo)

\begin{tabular}{|c|c|c|c|c|c|c|c|c|c|c|}
\hline & Unidade & Ano & \begin{tabular}{|c|} 
Nova \\
Zelândia
\end{tabular} & \begin{tabular}{|r|} 
Estados \\
Unidos
\end{tabular} & Austrália & Inglaterra & Noruega & Japão & Coréia & $\begin{array}{c}\text { Brasil } \\
(* *)\end{array}$ \\
\hline Área & Km2 (000) & 1995 & 266 & 9.373 & 7.687 & 245 & 324 & 378 & 99 & 8.547 \\
\hline População & 1.000 .000 & 1995 & 3.6 & 263 & 18 & 58,6 & 4,4 & 125,3 & 44,8 & 164.4 \\
\hline Densidade & habitantes / Km2 & 1995 & 13 & 28 & 2 & 240 & 14 & 330 & 452 & 19 \\
\hline \multicolumn{11}{|l|}{ Estatísticas Vitais } \\
\hline Taxa de nascimento & por 1.000 habitante & 1995 & 16,4 & 16,0 & 14,5 & 13,5 & 13,6 & 10,0 & 14,9 & 21,4 \\
\hline Taxa de mortalidade & por 1.000 habitante & 1995 & 7,8 & 8,5 & 7,1 & 11,0 & 10,0 & 7,1 & 5,5 & 7,0 \\
\hline Taxa de mortalidade infantil & por 1.000 & 1995 & 7,1 & 8,5 & 5,8 & 6,6 & 5,0 & 4,2 & 11,0 & 56 \\
\hline Expectativa de vida ao & nascimentos & & & & & & & & & \\
\hline \multirow[t]{2}{*}{ nascer } & homens & 1993 & 73 & 73 & 75 & 73 & 74 & 76 & 69 & 65 \\
\hline & mulheres & 1993 & 79 & 80 & 81 & 78 & 80 & 82 & 76 & 70 \\
\hline PIB & & 1995 & 52 & 6.840 & 333 & 1.056 & 113 & 4.750 & 387 & 555 \\
\hline PIB per capita $(*)$ & $\%$ anual & 1995 & 14,400 & 26,000 & 18,500 & 18,000 & 26,000 & 38,00 & 8,600 & 2,970 \\
\hline Crescimento do PIB & & 1995 & 2.5 & 2.2 & 2.3 & 1.5 & 3.1 & 1.2 & 7.7 & 2,2 \\
\hline Comércio Exterior & & & & & & & & & & \\
\hline $\begin{array}{l}\text { Importações - bens e } \\
\text { serviços }\end{array}$ & bilhão US\$ & 1995 & 16 & 889 & 68 & 289 & 42 & 356 & 120 & 36 \\
\hline $\begin{array}{l}\text { Exportações - bens e } \\
\text { Serviços }\end{array}$ & bilhão US\$ & 1995 & 16 & 776 & 63 & 280 & 49 & 450 & 116 & 44 \\
\hline \multicolumn{11}{|l|}{ Contribuições Setoriais } \\
\hline Serviços & $\%$ do PIB & 1995 & 62 & 67 & 67 & 66 & 63 & 55 & 44 & 52 \\
\hline Força de trabalho & 1000 & 1995 & 1,730 & $124,95 d$ & 8,696 & 27,635 & 2,180 & 65,450 & 21,059 & 74 \\
\hline Taxa de desemprego & $\%$ & 1995 & 6,3 & 5,7 & 8,3 & 8,2 & 5,2 & 3,0 & 2,0 & 5,6 \\
\hline \multicolumn{11}{|l|}{ Saúde } \\
\hline Quantidade de médicos & por 1.000 habitante & 1991 & 1,9 & 2,4 & 2,3 & 1,4 & 2,2 & 1,6 & 1,0 & 1,3 \\
\hline Gasto com saúde & $\%$ PIB & 1993 & 5,7 & 4,4 & 5,6 & 5,5 & 5,8 & 5,0 & 0,1 & 2,6 \\
\hline $\begin{array}{l}\text { Gasto do setor privado em } \\
\text { saúde }\end{array}$ & $\begin{array}{c}\% \text { orçamento / } \\
\text { residência }\end{array}$ & 1993 & 2,9 & 5,2 & 4,0 & 1,6 & 2,3 & 2,9 & 4,5 & - \\
\hline Taxa de câmbio (\$NZ) & em 31.03 .95 & 1995 & 1,0 & 0,61 & 0,82 & 0,39 & 4,19 & 60,6 & 484,7 & 0.61 \\
\hline
\end{tabular}

(*) - média dos últimos 5 anos.

(**) - após o plano Real .

Fonte: Nova Zelândia: http://www.govt.nz ; Banco Mundial - Relatório sobre o Desenvolvimento Mundial 1996

O sistema fiscal da Nova Zelândia foi simplificado, e a alíquota mais alta do imposto de renda de pessoas físicas é agora de 33\%, alinhada com a alíquota do imposto de renda de pessoas jurídicas.

Alegar que as reformas na Nova Zelândia não foram dolorosas seria faltar com a verdade. O povo experimentou queda em seu padrão de vida e muitos trabalhadores perderam seus empregos como resultado das mudanças estruturais.

\section{Suportes conceituais da reforma}

Reformas administrativas não constituem processos inovadores, típicos da atualidade: de fato, como afirma Kettl, ${ }^{34}$ "if there is anything more ageless than government itself, it is the effort to improve it".

No entanto, a reforma atual diferencia-se das demais em, pelo menos, dois pontos: primeiro, por seu caráter universal, ou seja, constituir um movimento no qual todos os países estão se engajando; segundo, por apresentar, de forma homogênea, a mesma base conceitual, qual seja: o movimento gerencialista, a teoria da Public Choice e a teoria Principal-Agente. 
O movimento gerencialista preconiza para o setor público, a partir do modelo de competição de mercado, que a estrutura administrativa não seja superdimensionada de forma a superar as necessidades de governo. Eficiência, economia, produtividade constituem indicadores básicos para caracterizar uma boa administração. A ênfase, dentro do pensamento gerencialista, é na existência e na aplicabilidade prática de um conjunto de instrumentos gerenciais, que se acredita poderem ser aplicados universalmente, e em diferentes tipos de organizações, sejam elas públicas ou privadas.

A teoria da Public Choice defende os seguintes pontos básicos: ${ }^{35}$

1) incremento nos incentivos econômicos ou de mercado para a gerência do setor público;

2) os indivíduos são egoístas — agem racionalmente em direção ao próprio interesse;

3) a burocracia estatal é vista como participante ativa do governo, e os burocratas apresentados, diferentemente do modelo weberiano, como agentes dinâmicos que lutam para aumentar sua dotação orçamentária, para ampliar seu círculo de poder, e principalmente, para se manterem nos cargos;

4) os diversos agentes políticos são vistos como “egoístas', ou seja, a racionalidade de cada um visa, unicamente, maximizar seus próprios interesses;

5) nesse jogo de maximização de interesses cruzados e inter-relacionados, nessa arena de atores egoístas, o resultado final é o bem comum. Destaca, também, que o interesse individual é sempre diferente do interesse coletivo.

A teoria Principal-Agente parte do princípio de que, em um modelo ideal, os agentes oferecem seus serviços ao principal, e atendem perfeitamente às demandas e necessidades daqueles.

Além disto, a estrutura institucional do serviço público reforça a tendência em direção ao rent seeking, ou seja, os agentes somente atendem aos propósitos dos principais quando tais propósitos coincidem com os seus próprios interesses. Isto conduz a um tipo de assimetria entre os trabalhadores do setor público - que seriam os agentes - e o governo, que, presumivelmente, seria o principal: os primeiros, por deterem grande conhecimento institucional, poderiam ludibriar os principais a respeito dos processos burocráticos, dos quais são grandes conhecedores. Situação semelhante ocorre entre agências estatais que possuem monopólio sobre serviços e produtos: os consumidores principais desta relação não podem escolher um produto ou serviço alternativo ${ }^{36}$.

Trabalhando com a teoria Principal-Agente, Przeworsky ${ }^{37}$ propõe um modelo com quatro blocos de interação. $\mathrm{O}$ primeiro bloco seria da interação entre o Estado e os atores privados. O segundo refere-se à 
interação entre políticos x burocratas. No terceiro dá-se a relação entre cidadãos e políticos e por último, a relação entre burocratas e cidadãos.

1) Estado e atores privados: aqui, o Estado, como provedor das políticas públicas, é o principal enquanto os agentes privados, que têm uma tendência natural de procurar defender seus próprios interesses, seriam os agentes. Por isto, o Estado deve desenvolver e aplicar mecanismos de regulação, capazes de fazer com que os agentes funcionem em função do principal. Daí, quanto melhor for a qualidade da regulação, melhor será a qualidade da intervenção estatal. Seriam três os fatores primordiais para que uma boa regulação estatal se efetuasse: os interesses públicos deveriam se sobrepor aos interesses privados; manter a credibilidade do governo e garantir a permanência das "regras do jogo", e contar com uma boa rede de informações do governo sobre o funcionamento e os anseios dos membros do setor privado.

2) Políticos x burocratas: os burocratas do setor público seriam os agentes que deveriam ser conduzidos a agir em função do bem-estar público, e não em busca de seus próprios interesses; os políticos, como principais, devem estabelecer os controles, tais como: zelo nas contratações visando melhor produtividade; competição entre as diversas agências e descentralização administrativa, visando estabelecer uma maior proximidade entre burocratas e cidadãos.

3) No nível de relação entre cidadãos e políticos, o modelo prescreve que, sendo os políticos representantes dos cidadãos, eles são os agentes e os cidadãos os principais. A forma de controle mais eficaz é a não-reeleição dos maus políticos, o que, no entanto, é dificultado pela pouca visibilidade dos atos dos políticos.

4) Burocratas x cidadãos: os últimos são os principais, sendo os burocratas os agentes. Neste caso, deve-se estimular a cobrança da sociedade sobre a burocracia, no sentido de que cada órgão público tenha o seu ombudsman, capaz de ouvir as reclamações do público; que os cidadãos, prejudicados pela atuação pública, acionem o Poder Judiciário através de tribunais apropriados.

O grande problema na implementação de um modelo baseado na teoria principal-agente reside no âmbito das relações de poder, ou seja, que ou quais atores políticos terão a prerrogativa de definir quem será o agente e quem será o principal nas diversas cadeias de relacionamentos?

\section{Conclusões}

1) A partir de 1984, o governo da Nova Zelândia deu início a uma grande reforma do setor público, cujo objetivo principal foi a rentabilidade comercial. A partir daí, qualquer meta social a ser implementada pelas 
empresas estatais deveria ser, preliminarmente, aprovada pelo Parlamen-

to e financiada pelo orçamento público. Além disto, as empresas estatais foram postas na mesma situação jurídica das empresas privadas, expostas à concorrência e forçadas a buscar financiamento em condições de mercado, sem garantias públicas.

A propriedade das empresas saíram dos ministérios setoriais, passando ao controle direto do novo ministro das Empresas Estatais e ao Tesouro. Estes passaram a nomear a diretoria de cada empresa, as quais passaram a ser compostas quase exclusivamente por representantes do setor privado. Esses diretores nomeavam os administradores das empresas, a partir dos contratos de performance, fixando e controlando objetivos anuais, com a prerrogativa de demiti-los em caso de fracasso administrativo.

O governo do Partido Nacional, eleito em 1990, privatizou várias dessas empresas a despeito do lucro e da produtividade crescente por trabalhador, resultantes das iniciativas precedentes. A justificativa para a privatização foi o receio de não se conseguir sustentar, a longo prazo, as reformas. Este receio teve origem na premissa de que, em tempos de vacas magras, os governos conseguem tomar medidas saneadoras, priorizando os objetivos comerciais, concedendo autonomia aos administradores e adotando orçamentos rigorosos, mas passada a crise ou à vista de interesses políticos importantes, a prioridade empresarial desaparece, cedendo espaço aos interesses corporativos. Isto é particularmente dramático para as empresas que são consideradas estratégicas do ponto de vista eleitoral.

O modelo de privatização adotado atingiu a maioria das empresas estatais, ficando fora do programa a empresa encarregada da distribuição de energia elétrica, os institutos de pesquisa - Crown Research Institutes (CRI) e as empresas de saúde - Crown Health Enterprises (CHE).

2) Os dados contidos na Tabela 4, 5 e 6 merecem alguns comentários. Primeiramente, cumpre ressaltar que os países comparados, excetuando-se a Coréia e, principalmente, o Brasil, acham-se no estreito círculo das mais ricas e desenvolvidas nações do mundo. Já superaram alguns aspectos críticos ainda presentes para os países em desenvolvimento, como analfabetismo, acesso aos recursos relacionados à saúde, má distribuição de renda, etc. Basta, por exemplo, comparar a situação desses dois países, em termos de taxa de mortalidade infantil, ou de renda per capita para visualizar este aspecto. Portanto, a comparação entre resultados de reformas deverá, pelo menos preliminarmente, levar em consideração o grau de desenvolvimento sócio-econômico de cada país.

Em segundo lugar, a área física, medida em $\mathrm{Km}^{2}$, parece não ser uma variável relevante, caso o grupo de comparação seja homogêneo em termos de desenvolvimento sócio-econômico. Assim, tanto países 
com grande extensão geográfica, como EUA e Austrália, quanto países pequenos, como Inglaterra, Noruega, Japão, Nova Zelândia, apresentam indicadores estatísticos vitais e PIB per capita sem grandes discrepâncias. Na Coréia, por outro lado, observa-se uma quase ausência do Estado no setor saúde, evidenciado tanto pela percentagem do PIB gasto no setor saúde quanto pela percentagem do orçamento familiar gasto com a saúde. Este fato é agravado pelo indicador quantidade de médicos por 1.000 habitantes, onde apresenta a mais baixa relação dentre os demais países, refletindo este fato na taxa de mortalidade infantil, que é a mais alta.

Em terceiro lugar, parece ficar evidente, a partir das três tabelas, que o resultado positivo das reformas condiz com a manutenção e mesmo o aumento das despesas com o setor social (considerado aqui como educação, saúde, previdência social, habitação e serviços comunitários). Tanto a Austrália quanto a Nova Zelândia, que anteriormente já despendiam cerca de $50 \%$ do total das despesas na área social, aumentaram ainda mais esse percentual no período pós-reforma.

Por último, a abertura do mercado interno às importações comportou-se, tanto Nova Zelândia quanto na Austrália, no sentido de compensar o déficit global da economia, ou seja, parece ter sido utilizada uma política de incentivo às exportações associada à melhoria na performance e na produtividade das empresas, de forma a compensar o aumento, em quantidade de dólares, das importações. Portanto, a reforma não foi realizada em troca do sacrifício das empresas nacionais, sejam elas estatais ou privadas.

3) Enquanto a Public Choice defende a não-intervenção estatal, e no limite, a inutilidade do Estado, aceitando como ideal a regulação total pelo mercado, a teoria Principal-Agente baseia-se na necessidade de coordenação dos esforços para consecução dos objetivos e metas das organizações, prescrevendo controle e intervenção, e mesmo, a necessidade de intervenção estatal permanente, devido mesmo ao agir egoísta dos agentes privados. Traduzindo melhor a contradição: enquanto a primeira corrente teórica preconiza estratégias tipicamente mercadológicas, a segunda possui uma fundamentação na dimensão social.

Na prática, essa contradição acha-se localizada, por exemplo, na sustentação dos objetivos e prioridades sociais do Estado na Nova Zelândia. Enquanto as empresas estatais devem se guiar por metas tipicamente comerciais, a fixação dos objetivos sociais deve ser aprovada, antecipadamente, pelo Parlamento e inscrita no orçamento público. $\mathrm{Ou}$ seja, pode ocorrer uma dada situação na correlação de forças políticas que propicie o Parlamento se negar a fixar qualquer meta social (por exemplo, a extensão de energia elétrica para comunidades não-lucrativas), prejudicando o cidadão menos privilegiado, ou o Parlamento passar 
a aprovar determinadas medidas sociais, as quais passam a inviabilizar economicamente as empresas estatais.

4) A experiência reformista da Nova Zelândia constitui um processo em andamento, com vários elementos ainda em progresso. Entretanto, dois aspectos e duas lições básicas podem ser citados a partir da atual experiência reformista. O primeiro aspecto é a necessária firmeza na determinação em se realizar as reformas e a certeza de que os benefícios serão colhidos no futuro. Uma máxima popular pode ser utilizada para clarear esse pensamento: "não se pode cruzar um abismo com dois pulos". ${ }^{37} \mathrm{O}$ segundo aspecto refere-se à necessidade de distinguir e reconhecer, claramente, as especificidades dos setores e dos mercados que se deseja reformar. Assim, o setor de saúde e o setor de ciência e tecnologia, devido às suas características especiais, tiveram um tratamento diferenciado.

A primeira lição a ser tirada é simples: é melhor com reforma do que sem ela. Os dados apresentados nas diversas tabelas no decorrer do artigo respondem por si mesmos. A segunda lição refere-se à necessidade de um investimento financeiro inicial nas empresas a serem corporatizadas ou privatizadas, para adaptá-las ao ambiente de mercado. A não compreensão desse fato pode jogar por água todo o esforço realizado.

5) Finalmente, o estudo ora realizado baseou-se em fontes secundárias, o que, se por um lado não lhe tira o valor, pelo menos sugere a importância de se aprofundar em novas pesquisas, principalmente as de caráter prioritariamente analítico e comparativo, baseadas no estudo de dados primários que garantem uma análise mais acurada desta experiência. 
1 Este artigo foi realizado com recursos da ENAP Escola Nacional de Administração Pública. Constitui um dos produtos da pesquisa sobre burocracia estatal, do Programa de Pesquisas e Estudos sobre Reforma do Estado e Governança, mantido pela FGV/EBAP, sob a coordenação da professora de mestrado em administração pública e doutora em ciência política Sonia Fleury. Contou, além da atuação do autor como pesquisador-adjunto do Programa, com a contribuição especial dos seguintes pesquisadores: Adriana Mesquita, Sílvia Ferreira e Valdei Araújo.

2 "O conflito Leste-Oeste ocultou a emergência de forças que agem desde 1950 e que aparecem como elemento chave para a organização internacional: a globalização econômica e cultural, a massificação das trocas comerciais, a emergência das questões planetárias, as migrações demográficas, por exemplo." Marisol Touraine. Le Bouleversement du Monde. Géopolitique du XX1e Siècle. Paris, 1995, p. 198. Ver também: Fleury, Sonia. Saúde e Qualidade de Vida: combater a desigualdade e a exclusão. Setembro, 1996.

3 Richardson, Ruth. The New Zealand Public Sector. Brasília: Mare. 1996, p. 102.

4 Herman Schwartz. Public Choice Theory and Public Choices. Bureaucrats and State Reorganization in Australia, Denmark, New Zeland, and Sweden in the 1980s. Administration \& Society, v.26, 1994, p.52.

5 Gerald Caiden. Reformas Administrativas Recientes en Australlia. Revista Internacional de Ciencias Administrativas. Madrid. v.57, n. 1, março/91, p. 9.

6 Jonathan Boston. Assessing the Performance of Departamental Chief Executives: Perspectives from New Zealand. Public Administration. v.70. Agosto 1992, p.407.

7 Organization for Economic Cooperation and Development - OECD - 1979 Employment in the public sector. Paris, citado por Schwartz, op. cit, p. 51.

8 Jonathan Boston. Transforming New Zealand's public sector: Labour's quest for improved efficiency and accountability. Public Administration, v. 65, 1987, p. 427.

9 Jonathan Boston. op. cit., p.431.

10 Richardson, 1996, op. cit., p.102.

11 Boston, 1987, op.cit., p.432.

12 Richardson, 1996, op. cit., p.103.

13 State-Owned Enterprises Act, 1968, Seção 4 - citado por Boston, op.cit, 1987, p. 433.

14 McKinlay. Corporatisation: the solution for state-owned enterprise? Wellington: Victoria University Press, 1987, apud. Boston, op.cit. 1986, destaca os seguintes benefícios dessa prática: a) pelo cálculo do custo para os serviços não-lucrativos, é possível avaliar acuradamente a performance comercial de cada empresa; b) os serviços subsidiados passam a sofrer um maior escrutínio público, tornam-se abertos, e possibilitam uma política eficaz de controle. De outra forma, o Treasure passa a cobrar dos ministros uma justificativa para a prorrogação dos subsídios, ou procurar uma forma mais barata para alcançar os mesmos resultados.

15 A colocação em prática desse princípio exigiu grandes mudanças em termos de legislação: liberalização de mercados e eliminação de protecionismos; cancelamento de subsídios financeiros; pagamento de taxas e dividendos ao governo por parte das SOE's; eliminação da exigência de que agências do governo, sempre que possível, efetivassem suas compras em outras agências governamentais; reforma do sistema de pagamento fixo de salários, para dar maior competitividade às empresas públicas. Boston, op. cit., 1987, p.434.

16 Segundo Boston, op. cit., 1987, 95\% dos 2 mil ou mais instruções contidas no Public Service Manual foram eliminadas. O manual foi totalmente reescrito, dando-se preferência por dotá-lo com princípios gerais, para orientação dos administradores,e não por rígidas prescrições formais. 
17 O princípio norteador é que a responsabilidade pelo estabelecimento das políticas e dos objetivos das agências públicas cabem ao ministro, além de aprovar as estratégias para alcancá-los. Ao mesmo tempo, garante aos administradores das agências um mínimo de interferência política.

18 Para informações detalhadas sobre a reforma eleitoral na Nova Zelândia, ver: Vowles, Jack. The Politics of Electoral Reform in New Zealand. International Political Science Review, v.16, n.1, p.95-115 1995.

19 Até a metade de 1987, cerca de 5 mil empregados públicos solicitaram demissão voluntária e mais ou menos 200 se aposentaram precocemente. O custo para o Estado ficou em torno de 100 milhões de dólares. Além disto, mais de 2.000 funções públicas foram extintas durante o período 1986/1987 como resultado da comercialização dos vários serviços públicos. Boston, 1987, op.cit., p.436.

${ }^{20}$ Há de se destacar que, tanto na região de mineração como na florestal, o índice de desemprego, anterior às reformas, era o mais alto do país, o que agravou ainda mais a situação dos atingidos pela reforma. Além disto, a grande maioria dos postos de trabalho extintos pertenciam às minorias étnicas. Boston, 1987, op. cit., p.436.

21 A reforma de 1912 criou uma carreira de serviço público, de caráter permanente, unificada, politicamente neutra e meritocrática. Jonathan Boston, 1987, op.cit., p.424.

22 Basil Walker. Reforming the public sector for leaner government and improved performance: The New Zealand experience. Public Administration and Development. v.16, p.354, 1996

23 Jonathan Boston, 1987, op.cit, p. 424.

24 Jonathan Boston, op. cit, p. 429.

25 Rob Laking. Developing a culture of success: Reflections from New Zealand experience. Public Administration and Development. v.15, 1995, p. 284.

26 Ainda hoje o débito público na Nova Zelândia acha-se em níveis bastante altos, estando a economia vulnerável diante de eventos adversos. Richardson, op.cit., p.112.

27 Exemplo de plano corporativo pode ser obtido em: Nova Zelândia: http:// www.mdcentre.govt.nz//cplan95.htm

28 Jonathan Boston, 1992, op.cit. p. 411.

${ }^{29}$ Herman Schwartz, 1994, op.cit., p. 60.

${ }^{30}$ Para os novos administradores, o modelo prescreve que deverão receber em torno de 95\% da base salarial, prevendo-se incrementos a partir daí, até o máximo de $110 \%$ da base salarial. Uma escala de 1 a 5 é utilizada pelo SSC para decidir a magnitude dos incrementos salariais. Jonathan Boston, 1992, op. cit., p. 409 e 424-425.

31 Apud Jonathan Boston, 1992, op.cit., p. 414.

32 New Zealand. Statistics. http://www.mdcentre.govt.nz/stats/2eoa_272.html, 1996.

33 Peter Osborn. Remodelação da Nova Zelândia supera em brilho a da Austrália. In: Ohmae, Kenichi. O fim do Estado Nação. Editora Campus. Rio de Janeiro, 1996., p.173-176.

34 Donald Kettl. Reforming Government Sector Management. Brasília, MARE, 1996, p.38.

35 R.C. Mascarenhas. Building an enterprise culture in the Public Sector: Reforma of the Public Sector in Austrália, Britain and New Zealand. Public Administration Review, v.53, n.1, jul./agos 1993, p.319-328.

36 Herman Schwartz, 1994. op.cit., p.56.

37 Adam Przeworsky. On the Design of the State: A Principal-Agent Perspective. Brasília. MARE, 1996. O modelo de Przeworsky, apesar de não ter tido impacto na reforma administrativa da Nova Zelândia, pelo menos na sua fase mais recente, está sendo citado com o objetivo de contribuir para um maior entendimento da questão teórica.

38 Presidente Václav Havel, da República Tcheca. Apud Relatório Anual do desenvolvimento Mundial. 1996, p.9. 


\section{Referências bibliográficas}

BIRD - Banco Mundial. Relatório Anual sobre o Desenvolvimento Mundial. Washington, 1986.

. Relatório Anual sobre o Desenvolvimento Mundial. Washington, 1996.

Boston, Jonathan. Transforming New Zealand's public sector: Labour's quest for improved efficiency and accountability. London: Public Administration, v.65, Winter 1987, p. $423-442$.

.Assessing the performance of departamental chief executives: perspectives from New Zealand. London: Public Administration: an international. v.70, Autumn,1992.

Bronsnan, Peter; Rea, David; Wilson, Moira. Labour Market Segmentation and State. The New Zealand Experience. London:, Cambridge Journal of Economics, v.19 n.5, october, 1995.

CAIDEN, Gerald E. Reformas Administrativas recientes en Australásia. Revista Internacional de Ciencias Administrativas. Madrid, v.57, n.1, marzo 1991, p. 9-26.

CAtalà, J.Prats. El Nuevo Juego y sus Reglas: Construyendola Nueva institucionalidad en la America Latina de los 90. Barcelona, 1996.

CROZIER, Michael. Etat modeste, Etat moderne, Paris, Fayard, 1987.

Cómo reformar al Estado. (Trad.): Rosa Cusminsky de Cendero Fondo de Cultura Económica México - 1ª edição: 1992.

HeLd, David. “A democracia, o Estado-Nação e o sistema global”. In: Lua Nova. Março de 1991.

Jun, Jong S. La Reforma Administrativa En La Zona De La Orla Del Pacífico. Madrid: Revista Internacional de Ciencias. Administrativas. v.57 n.1, marzo 1991.

KetTL, Donald. The Global Revolution: Reforming Government Sector Management. In: Reforma do Estado na América Latina e no Caribe: Rumo a uma Administração Pública Gerencial Seminário Internacional - MARE/BID/ONU. Brasília,1996.

KnotT, Jack H. Comparing Public and Private Management: Cooperative Effort and Principal-Agent Relationships. Journal of Public Administration Research and Theory. vol. 3, n. 1, 1993, p. 93-119.

Laking, Robert. Developing a Culture of Success: Reflections From New Zealand Experience. London: Public Administration and Development, v.15, n.3, August, 1995, p.283-294.

Mascarenhas, R.C. Building an Enterprise Culture in the Public Sector: Reform of the Public Sector in Australia, Britain, and New Zealand. Public Administration Review. v.53, n 4, July/August, 1993, p. 319-328.

New Zealand. The Management Development Centre. Corporate Plan 1995/96. http:// www.mdcentre.govt.nz

Osborn, Peter. "Remodelação da Nova Zelândia supera em brilho a da Austrália" In: Ohmae, Kenichi. O fim do Estado Nação. Editora Campus. Rio de Janeiro, 1996, p.173-176.

Pereira, Luiz Carlos Bresser. Plano Diretor da Reforma do Aparelho do Estado. Brasília, 1995.

PrZeworsky, Adam. "On the design of the state: a principal agent perspective" In: A Reforma do Estado na América Latina e no Caribe: rumo a uma Administração Pública Gerencial. Seminário Internacional - MARE/BID/ONU. Brasília, 16 e17/05/96. 
Richardson, Ruth. "The New Zealand Public Sector Reforms". In: A Reforma do Estado na América Latina e no Caribe: rumo a uma administração pública gerencial. Seminário Internacional - MARE/BID/ONU. Brasília, 16 e17/05/96, p.99-120.

Schwartz, Herman M. Public Choice Theory And Public Choices: Bureaucrats And State Reorganization In Australia, Denmark, New Zealand, and Sweden in the 1980s. Administration \& Society, v. 26, n.1, May, 1994, p.48-77.

Touraine, Marisol. Le Bouleversement du Monde. Géopolitique du XXI ${ }^{\mathrm{e}}$ Siècle. Paris: Seuil, 1995.

Uttey, Stephen. Adapting To Radical Innovation: Accident Compensation In New Zealand. Miami: Policy Studies Review , v. 12 n.1/2, 1993.

Vowles, Jack. The Politics of Electoral Reform in New Zealand. International Political Science Review. v.16, n.1, January 1995, p.95-115

WALKER, Basil. Reforming the public sector for leaner government and improved performance: The New Zealand experience. Public Administration and Development. v.16, 1996, p.353-375.

Weber, Max. “Os tipos de dominação”. In. Economia e Sociedade - Fundamentos da Sociologia Compreensiva, v.1, Trad.: de Regis Barbosa e Karem Elsabe Barbosa; Rev. Técnica de Gabriel Cohn, Brasília, D.F.: Ed. UnB, 1991. 


\section{A reforma administrativa da Nova Zelândia nos anos 80-90: Controle estraté- gico, eficiência gerencial e accountability \\ Wagner Carvalho}

$\mathrm{O}$ artigo discute o processo de reforma administrativa implementada na Nova Zelândia a partir de 1984, com a chegada do Partido Trabalhista ao poder, abordando seus principais desdobramentos nos anos 90. Parte de uma apresentação do modelo administrativo em vigor na Nova Zelândia antes das reformas empreendidas em 1984, delimitando dessa forma o quadro referencial para comparar a situação anterior com a atual, de maneira que proporcione uma avaliação sobre os impactos das medidas empreendidas. Em seguida, apresenta uma descrição dos objetivos e princípios norteadores da reforma tais como, separação das funções comerciais das não-comerciais; separação entre as funções administrativas e de assessoria; princípio do "quem usa paga", user pays; transparência na concessão de subsídios; neutralidade competitiva, descentralização e aumento do poder discricionário do administrador; melhoramento da accountability, entre outros. A seguir, são apresentadas as principais medidas empreendidas pelo governo trabalhista entre 1984 e 1990, dando ênfase à metodologia adotada para a implementação e accountability dos contratos de gestão firmados entre os executivos-chefe e os ministros. Posteriormente, o autor apresenta as modificações introduzidas nas regras de contratação de pessoal no serviço público neozelandês e, de um modo mais geral, na política de recursos humanos. Finalmente, é traçado um perfil da situação atual da Nova Zelândia, bem como é feita a apresentação sucinta daqueles que o autor considera como sendo os "suportes conceituais da reforma": o movimento gerencialista, a teoria do Public Choice e a teoria Principal-Agente.

\section{La reforma administrativa de Nueva Zelandia en los años 80-90: Control estra- tégico, eficiencia gerencial y accountability \\ Wagner Carvalho}

El artículo discute el proceso de reforma administrativa que se está llevando a cabo en Nueva Zelandia a partir de 1984, con la llegada del Partido Laborista al poder, enfocando sus principales despliegues en los años 90. Parte de una presentación del modelo administrativo en vigor en Nueva Zelandia antes de las reformas emprendidas en 1984, delimitando de esa manera el cuadro de referencia para comparar la situación anterior con la actual, de tal forma que proporcione una evaluación de los impactos de las medidas adoptadas. En seguida presenta una descripción de los objetivos y principios que nortearon la reforma, tales como separación de las funciones comerciales de las no comerciales; separación entre las funciones administrativas y de asesoramiento; principio de "quien usa paga", user pays; transparencia en la concesión de subsidios; neutralidad competitiva, descentralización y aumento del poder discrecional del administrador; y mejoramiento de la accountability, entre otros. A continuación se presentan las principales medidas adoptadas por el gobierno laborista entre 1984 y 1990, dando énfasis a la metodología seguida para la puesta en marcha y la accountability de los contratos de gestión firmados entre los ejecutivos-jefes y los ministros. Posteriormente, el autor presenta las modificaciones introducidas en las reglas de contratación de personal en el servicio público neozelandés y, de manera más general, en la política de recursos humanos. Finalmente, se traza un perfil de la situación actual de Nueva Zeladia, haciendo, además, la presentación sucinta de los que el autor considera como siendo los "soportes conceptuales de la reforma": el movimiento gerencial, la teoría de la Public Choice y la teoría del Principal-Agente. 
Administrative reform in New Zealand in the 80s and 90s: strategic control, managerial efficiency and accountability

Wagner Carvalho

This article discusses the administrative reform process implemented in New Zealand as of 1984, when the Labor Party came to power, and addresses its major developments in the 90s. It starts with an explanation of the administrative model in effect in New Zealand prior to the reforms undertaken in 1984, thus establishing the reference framework in which to compare the previous state of affairs vis-à-vis the current one in such a way as to provide an assessment of the impact of the measures introduced. The article then goes into a description of the major reform objectives and principles, such as separation of commercial and non-commercial functions; separation of administrative and advisory functions; the user pays principle; transparency in the granting of subsidies; competitive neutrality; decentralization and increase in administrators' discretionary power; improvement in accountability, among others. The main measures carried out by the Labor government between 1984 and 1990 are then highlighted, with special emphasis on the methods used to ensure implementation and accountability of management contracts entered into by top executives and ministers. The article further addresses the changes introduced in the rules governing personnel contracting in New Zealand's civil service and, in a more general sense, in the human resources policy. Finally, an outline of the current situation in New Zealand is drawn, followed by a brief discussion of the "conceptual underpinnings of the reform", namely the managerialist movement, the Public Choice theory and the Principal Agent theory. 